\title{
Critical Multicultural Citizenship Education among Black Immigrant Youth: Factors and Challenges
}

\author{
Alex Kumi-Yeboah \\ State University of New York-Albany \\ U. S. A. \\ Patriann Smith \\ Texas Tech University \\ U. S. A.
}

ABSTRACT: This study uses qualitative interviews with 18 participants across five states to examine the factors that promote enhancement of critical multicultural education for Black immigrant youth. Findings suggest that class discussion, influence of social media and technology, non-educational practices, and cultural and language differences are the leading factors that promote the advancement of critical multicultural citizenship education for participants. Participants utilized these factors to navigate the democratic education and the role of transnational identification. Findings support the need for teachers and educators to understand the cultures and best practices for teaching immigrant youth.

KEYWORDS: Black immigrant youth, social media, critical citizenship, transnational, inquiry-based learning

\author{
Theoretical Framework \\ Methods \\ Findings \\ Discussions and Implications \\ Notes \\ References \\ Appendix A - Interview Protocol \\ Author Contact
}

The Immigration Act of 1965 (which became effective in 1968) paved the way for an increasing number of immigrants to the United States. The act liberalized American immigration policy, abolishing the quota system based on immigrants' national origins, and liberalized American immigration policy (Banks, 2008). Before 1968, most immigrants who migrated to the United States came from Europe. However, the trend changed in the $21^{\text {st }}$ century as most immigrants now come from Asia, Latin America, the Caribbean, and Africa (American Community Survey, 2012; U.S. Census Bureau, 2010).

According to United States Census Bureau (2014), a record 3.8 million Black immigrants live in the United States today, more than four times the number in 1980. The population of foreign-born Blacks (Africa and the 
Caribbean) has grown from $3.1 \%$ of the Black population in 1980 to $8.7 \%$ in 2013. By 2060, $16.5 \%$ of the U.S. Black population will be foreign-born blacks (American Community Survey, 2014). More recently, the population of African immigrants almost doubled (McCabe, 2011) growing from 881,100 in 2010 to 1,606,914 in 2012.

Currently, a large influx of U.S. Black immigrant youth come from heritage countries with educational and cultural backgrounds that are different from the systems in the United States. For example, a number of youth migrate from undemocratic counties with little or no political discourse at school that facilitates discussions surrounding democratic citizenship education (Waters, 1999). The histories and backgrounds of Black immigrant youth reflect the complex ways in which they engage in teaching and learning, specifically in the context of advancing critical multicultural citizenship education.

As a result of these demographic changes and their ramifications, teachers and policy makers have been tasked to find ways to help Black immigrant youth assimilate and transition into U.S. schools. Specifically, there is the need to examine and promote multicultural citizenship education to enhance democratic education (Banks, 2008; Knight \& Watson, 2014; Ramakrishnan \& Bloemraad, 2008) for these immigrant youth. Multicultural citizenship education is defined here as the process of providing opportunity for students and teachers to critically examine the curriculum through multiple perspectives in hope of gaining the skills necessary to become members of diverse and socially just communities (Dilworth, 2004).

Prior research by John Ogbu concerning minority students emphasized immigrant students' interest in participation in the destination culture and their degree of fit into the U.S. hierarchy of ethnicity and race (Gibson, 1989; Ogbu 1991; Olsen, 2001; Stepick \& Stepick, 2000; Suárez-Orozco \& Suárez-Orozco, 2001; Suárez-Orozco \& Suárez-Orozco,1995). In contrast, cultural conservatives have focused less on "fit" and claimed that all immigrant youth, regardless of their generation, will adapt to "American" culture such as dress, music and entertainment tastes, and food preferences (Konczal 2001; Waters, 1999), and will become Americanized and demonstrate a preference for the use of English (Portes \& Rumbaut, 2001). Notwithstanding, a significant number of immigrant youth align and identify themselves with their home country and place less emphasis on American identity (Alba \& Nee, 2003).

In most cases, teachers, educators, and policy makers are concerned about how immigrant youth at school could be taught the basics of civic and multicultural citizenship education to promote their allegiance and understanding of the values of American culture (Banks, 2007; Knight, 2011; Knight \& Watson, 2014). To date, the identifying factors that promote the enhancement of critical multicultural education among Black immigrant youth are understudied (Knight, 2011; Knight \& Watson, 2014). To contribute to this emerging area of research, we focus on the ways in which critical multicultural citizenship education is enhanced among Black immigrant youth in U.S. schools, the challenges faced by Black immigrant youth in the pursuit of multicultural citizenship education, and 
the educational implications for teachers and students.

\section{Theoretical Framework}

This study is primarily framed by critical multicultural citizenship education. According to Banks (2008), critical multicultural citizenship is the intersection of multicultural education and critical pedagogy (Apple \& Beane, 2007; Giroux, 2005). Critical multicultural citizenship education encompasses three main ideas. First, critical multicultural citizenship education assumes that the United States has not achieved full democratic status despite its accomplishments. Critical multicultural citizenship therefore calls for more knowledge about the injustices perpetuated by various institutions that impede the realization of democracy (Dilworth, 2004; McLaren, 1997). Second, critical multicultural citizenship education encourages students' critical reflection and consciousness, a locus that allows students to reflect on relationships between the situation and themselves. Third, critical multicultural citizenship invigorates collective action to transform institutional barriers to democracy. In tandem with the critical multicultural citizenship education framework, we also relied partially on Marri's (2005) classroom-based multicultural democratic education model, which consists of three elements: critical pedagogy, community building, and thorough disciplinary content.

Critical pedagogy engages students in social problem solving by encouraging them to think beyond the questions of how, why, when, and where (Freire, 1999). Community building allows teachers to create a climate of mutual respect that helps students build cordial relationships with one another and develop problem-solving skills (Browning, Davis, \& Retsa, 2000). Thorough disciplinary content emphasizes the teaching of mainstream academic knowledge, behaviors, and values that reflect views accepted by a given discipline. It incorporates transformative academic knowledge that helps students to challenge mainstream academic knowledge. The theoretical frameworks described above and chosen to undergird this study offer multiple lenses through which to assess how Black immigrant youth acquire the skills for social change and democratic education, and learn to make informed decision from multiple perspectives (Ladson-Billings, 2004; Ochoa-Becker, 2007; Parker \& Hess, 2001).

Furthermore, Koopmans, Statham, Giugni, and Passy (2005) defined citizenship as "the set of rights, duties, and identities linking citizens to the nationstate" (p. 7). Marshall (1964) divided citizenship into three categories, namely civil, political, and social. The civil aspect of citizenship provides citizens with individual rights such as the right to own property, freedom of speech, and equality before the law. The political aspect offers citizens the chance to exercise political power by participating in the political process. The social aspect gives to citizens the education, welfare, and health needed to participate in their cultural communities and in the national civic culture. Most of the social, cultural, and educational frameworks of citizenship education in the United States were 
framed by the assimilationist policy (a policy that requires citizens to give up their first language and culture to become full participants in the civic community of the nation-state) before the ethnic revitalization movements of the 1960s and 1970s (Graham, 2005; Young, 2000).

Several research studies (Banks \& Banks, 1999; Banks, 2008; DeJaeghere, 2007; Haste \& Hogan, 2006) contend that critical multicultural citizenship education enables students to develop decision-making and social skills needed to identify problems and that it fosters critical thinking. Moreover, critical multicultural citizenship education has been thought to help students acquire knowledge related to their homes, community cultures, and languages as well as to clarify their values and make collective civic action. For instance, Knight and Watson (2014) conducted a qualitative study of 16 second- and 1.5generation West African immigrants living in New York City and their understanding of identity construction and civic engagement. Findings show that African immigrant youth engaged in a multilayered view of civic teaching, learning, and action within and across contexts of families, identities, and schooling in the United States.

Similarly, Jensen's (2008) examination of immigrants' "cultural identity" as a source of civic engagement (p. 70) revealed that political/legal engagement as well as community involvement-such as bicultural skills and consciousnesscreated complex and varied contexts for students in developing their civic identities. Confirming these findings, studies of Indian American, Pakistani American, and Bangladeshi American youth (El-Haj, 2007; Maira, 2004) revealed that immigrant students have complex and intricate identities that include their countries of origin and local communities. This research affirmed that the cultural and national identities of immigrant youth are contextual, evolving, and continually reconstructed. These complexities may be present because immigrant youth maintain contacts and connections with their homeland cultures through popular cultural avenues such as films, websites, music, TV, cable TV, and technology (Maira, 2004). They may also be partially responsible for consistently lower levels of civic knowledge, skills, and participation demonstrated by immigrant adolescent youth in urban areas when compared to that of their counterparts (Levinson, 2012). Exploring this dynamic with Korean immigrants in Los Angeles's Koreatown, Moon and Park (2007) found the influence of American mass media to be a significant positive predictor of their acceptance of American cultural values.

Dei (2002) argues that citizenship education in Africa is centered within the local and global cultures and extends beyond specific moments of time. Promotion of citizenship education occurs when people interact among groups for participatory communal citizenship during festivals or funerals in which members have the opportunity to teach local history and culture, and engage in multiple forms of civic learning. Several researchers (Au, 2007; Gee, 2013; Hoechsmann \& Poyntz, 2012) have therefore recommended that teachers emphasize the use of media and technology to engage students in authentic citizenship learning experiences with others, construct knowledge, and 
communicate effectively. In one study focused on prospective teachers' ability to foster critical multicultural citizenship (Castro, 2010), findings showed that teaching strategies such as de-emphasizing the test, incorporating multicultural and critical content, and teaching multiple perspectives helped promote critical citizenship education.

Yet, according to Banks (2004a, 2008), both teachers and students in U.S. schools perceive immigrant students negatively as "Other." When immigrant students are marginalized and "Othered" in schools, they intentionally realign their ethnic identities and develop weak attachments to the nation-state. Greenbaum (1974) found that U.S. schools taught immigrant students hope and shame. Immigrant youth were made to feel ashamed of their home and community cultures but were given hope that once they culturally assimilated, they could join the U.S. mainstream culture.

Acknowledging immigrant youths' difficulties with civic engagement in schools, minority groups have long demanded that schools must reform the curriculum to reflect immigrant students' cultural identities, experiences, struggles, past histories, and possibilities (Nieto, 1999). They call for teachers and educators to adapt instructional strategies that are more culturally responsive to students from different cultural, racial, ethnic, and language groups (Au, 2006; Gay, 2000; González, Moll, \& Amanti, 2005). The result has been that citizenship education was largely attributed to knowledge and action activities, including voting, performing community service (Haste \& Hogan, 2006), and the knowledge of current events (Jensen \& Flanagan, 2008). Fewer studies by far have been identified to investigate the enhancement of critical multicultural education of Black immigrant youth in U.S. schools. This study will fill the knowledge gap that exists concerning the ways in which critical multicultural citizenship education can be enhanced among Black immigrant youth by drawing from these youth's own voices.

\section{Methods}

The purpose of the study was to examine the factors that promote the enhancement and awareness of critical multicultural citizenship education among Black immigrant youth. The study addressed the following research questions: (a) What factors promote the enhancement of critical multicultural citizenship education for Black immigrant youth, (b) What are the challenges that Black immigrant youth face in acquiring critical multicultural citizenship education, and (c) What are the educational implications of critical multicultural citizenship education for Black immigrant youth and for teachers? 


\section{Participants}

The focal participants were 18 Black immigrant youth from countries in Africa and the Caribbean Islands ( $n=14$ high school students, $n=4$ General Education Development (GED) students earning the equivalent of a high school diploma). The sample consisted of eight males and 10 females. Participants' ages ranged from 15 to 19 years at the time of interview. The sample of Black immigrant youth was diverse in terms of age, country of origin, state of residence, gender, grade level, and cultural background (see Table 1). The average number of years of participants' stay in the United States ranged from two to six years. Participants resided in Florida, Georgia, Maryland, North Carolina, and Texas. Participants lived primarily in the major cities of Atlanta, Baltimore, Charlotte, Dallas, Houston, Miami, Orlando, and Tampa. The above states and cities were chosen because they had a large number of African and Caribbean immigrants. Participants from Africa were originally born in the countries of Egypt, Ethiopia, Kenya, Liberia, Nigeria, and Somalia, and participants from the Caribbean originated from Haiti, Jamaica, and Cuba. Overall, 12 participants came from Africa and six originated from the Caribbean.

Table 1. Participant Demographics

\begin{tabular}{|c|c|c|c|c|c|c|}
\hline Name & Gender & Age & $\begin{array}{c}\text { Grade } \\
\text { Level }\end{array}$ & $\begin{array}{c}\text { Years } \\
\text { in U.S. }\end{array}$ & $\begin{array}{c}\text { Country } \\
\text { of Origin }\end{array}$ & Language(s) Spoken \\
\hline Aaron & M & 17 & $11^{\text {th }}$ & 3 & Jamaica & English, Patwah \\
\hline Baba & M & 16 & $10^{\text {th }}$ & 4 & Kenya & English, Kiswahili \\
\hline Asaawi & F & 18 & G.E.D. & 2 & Nigeria & Hausa, English \\
\hline Muhammed & M & 16 & $10^{\text {th }}$ & 2.5 & Somalia & Arabic, Somali \\
\hline Sally & F & 19 & G.E.D. & 3 & Haiti & $\begin{array}{c}\text { French, Creole, } \\
\text { English }\end{array}$ \\
\hline Danny & F & 15 & $9^{\text {th }}$ & 3.5 & Haiti & French, English \\
\hline Asif & M & 19 & G.E.D. & 2 & Ethiopia & English, Amharic \\
\hline Matilda & F & 16 & $9^{\text {th }}$ & 4 & Liberia & English \\
\hline Jabril & M & 18 & $11^{\text {th }}$ & 1 & Egypt & Arabic \\
\hline Limann & F & 19 & G.E.D. & .67 & Cuba & Spanish \\
\hline Princia & F & 17 & $10^{\text {th }}$ & 2 & Jamaica & English \\
\hline Anasta & F & 16 & $9^{\text {th }}$ & 1.5 & Kenya & English \\
\hline Seidu & $\mathrm{M}$ & 17 & $11^{\text {th }}$ & .83 & Somalia & Arabic, Somali \\
\hline Manuela & $\mathrm{F}$ & 18 & $12^{\text {th }}$ & 2.33 & Cuba & Spanish \\
\hline Sarepa & M & 16 & $10^{\text {th }}$ & 1.83 & Nigeria & English, Yoruba \\
\hline
\end{tabular}




\begin{tabular}{|l|l|l|l|l|l|l|}
\hline Destinaa & $\mathrm{F}$ & 18 & $12^{\text {th }}$ & 2 & Ethiopia & Amharic \\
\hline Josephine & $\mathrm{F}$ & 15 & $9^{\text {th }}$ & 3 & Kenya & English \\
\hline Sallassie & $\mathrm{M}$ & 17 & $10^{\text {th }}$ & 3.17 & Nigeria & English, Hausa \\
\hline
\end{tabular}

We used purposive sampling via the snowballing method to choose our first participants for the study. The purpose of using the snowballing method was to allow initial participants to inform other students who were interested in the study (Gall, Borg \& Gall, 2007). Participants in the study were 1.5-generation Black immigrant youth who were born in Africa or the Caribbean Islands and migrated to the United States to live with their parents or guardian. We use the term 1.5-generation to refer to Black immigrant youth who were born in Africa or the Caribbean to one or both parents and who had migrated to the United States to live with their parent or parents/guardian and attend school. First, we contacted the presidents and local community leaders of various African and Caribbean Associations via email and phone so that we could connect with participants' parents. Presidents of African/Caribbean Associations, pastors, and leaders of the local religious and community organizations affiliated with African and Caribbean residents in the various states assisted with the process of recruitment. Second, with parents' permission and assistance, we contacted their children to be interviewed. Third, we attended monthly meetings of African and Caribbean Associations in Atlanta, Baltimore, Charlotte, Miami, Orlando, and Tampa and made presentations about the rationale and objectives of the study. Parents who agreed for their children to participate in the study signed consent forms and gave us permission to interview their children. Fourth, we contacted students via their parents and scheduled interview dates and times at their convenience.

\section{Data Collection}

We obtained parental and student consent and approval for all participant interviews. Face-to-face interviews were conducted with participants who lived in Tampa, Orlando, Miami (Florida), Atlanta (Georgia), Charlotte (North Carolina), and Baltimore (Maryland). The remaining interviews were conducted via phone for student participants in Dallas and Houston (Texas). Interviews lasting between 60 to 90 minutes were conducted at students' residences between June 20, 2013, and September 29, 2014. We used semi-structured, in-depth interpretive interviews because it provided us more access to probe students for additional answers and an opportunity to generate rich data (Gall, Borg \& Gall, 2007). The language used by students was considered essential in gaining insight into their awareness and experiences of critical multicultural citizenship education (Creswell, 2009; Gall, Borg \& Gall, 2007). A semi-structured interview approach targeted students' experiences, awareness, and participation in multicultural citizenship education (see Appendix A for interview questions). All 
interviews were conducted in the English language and audio-taped. We used pseudonyms to identify participants when reporting the results of this study to maintain confidentiality.

\section{Data Analysis}

Atlas.ti software (Atlas.ti.7.5.2 2014 version) served as a means of analyzing data from the 18 interview transcripts via constructivist grounded theory (Charmaz, 2006). Constructivist grounded theory is based on an iterative, inductive approach to data analysis. We read through all interview transcripts thoroughly and independently coded 18 interviews line-by-line to identify factors and challenges described by the study participants. Memos and comments were attached to quotes during coding and in subsequent reviews of groupings of data. We used categories and responses from the data to code participants' responses with assigned labels. Interview text was given codes to mark factors and challenges of Black immigrant youth in promoting critical citizenship education. We coded the text, and similar codes were sorted and analyzed together (e.g., "class discussions, class project;" "social media, watching television;" "parents teach, discuss politics;" "language and cultural challenges") to determine common themes derived from the data. Memos and comments were attached to quotes during the coding process.

We asked three peer reviewers to read through all the data; they also coded segments into categories and themes. This helped to triangulate and establish credibility for the data. Major themes were developed from the categories and compared with the themes selected by the peer reviewers. Our final step involved contacting participants to obtain their views concerning the interview transcripts and to authenticate credibility of our interpretations via the process of member-checking (Merriam, 2009). Through this process, participants were given the chance to review and make the necessary corrections to the contents of the interview after transcription. They reviewed transcripts and asked questions regarding categories and codes we selected from the data to ensure that the study resonated with understandings of the factors that promote the enhancement of critical multicultural citizenship education among Black immigrant youth (Lincoln \& Guba, 2000). This helped to reduce the impact of our biases and increase reliability. To further validate findings of the study, three reviewers, who are full professors of multicultural education, read through all the subsets of the transcripts and determined codes with assigned labels. This process helped to maintain trustworthiness, authenticity, and credibility of the data (Creswell \& Miller, 2000). 


\section{Findings}

The research questions that guided this study enabled us to conceptualize students' understanding and knowledge of citizenship education. First, we highlighted the major factors that influenced Black immigrant youth's understanding and advancement of critical multicultural citizenship education at school. Second, we specifically looked at ways in which the awareness and knowledge of critical multicultural citizenship education had shaped the understanding of Black immigrant youth about democratic education and the challenges they face in learning critical multicultural citizenship education at school. Third, we highlighted the implications of teaching immigrant youth critical multicultural citizenship education, focusing on what instructional strategies teachers need to use.

Overall, we identified the following themes through our iterative and analytical examination of the data sets: (a) the influence of class discussion and inquiry-based learning; (b) the influence of social media and technology; (c) the impact of non-educational practices; and (d) the effect of cultural, social, and language differences.

\section{The Influence of Class Discussion and Inquiry-Based Learning}

Most of the participants (15 out of 18) noted that the practice of classroom discussion increased their understanding of critical multicultural citizenship education. They referenced class discussions as a process that helped them to share their experiences with other students in civics, global education, and citizenship education. Participants expressed that class discussions allowed them the opportunity to reflect on past experiences in democracy and learn new concepts about governments and current events that affect humankind in the world. For example, Seidu, a participant from Somalia, noted: "I learned much about civic and global issues in my history and geography classes because I have the chance to ask questions and discuss issues on the right to vote, good citizen, and poverty in society."

Seidu's statement is a reflection of how participants acquired knowledge of critical multicultural citizenship education via class discussions and inquirybased learning. Most participants reiterated that the "open-communication" nature of class discussions allowed them to acquire knowledge about citizenship education and also helped them to develop a deep understanding on how take action and make viable decisions to solve individual and group problems. Anasta, a high school student from Kenya, stated:

I have learned so much about the civil, political, and cultural understanding of people in this state. Classroom discussions helped me to understand what it means to have identity and same time contributes to 
world community. I have the chance to say my mind about the problems in my country and how it affects the world. In history class, we learned about the benefits of voting, helping your community and paying tax as a citizen. (Anasta, Interview, 11/14/2013)

By describing the benefits and knowledge she gained from class discussions, Anasta expressed how Black immigrant students acquire knowledge in civics and citizenship education in school through class discussions and inquiry-based learning. Another participant (Manuela) also expressed how class discussion helped her to acquire knowledge in critical multicultural citizenship education as a result of questions and skills teachers used in class for them to understand the concepts, ideas, and benefits of critical citizenship education. She noted: "I like the way we build understanding of ideas in class, I like the group work we do in class about United Nations Project where we discussed the benefits and challenges." Manuela's statement reflects the views of most participants (16 out of 18), expressing that class discussions and presentations helped them to share their opinions, experiences, and understanding of social issues, current events, and to take actions. Class discussions helped participants to gain knowledge and awareness of how cultural, social, national, regional, and global identifications are interrelated, complex and evolving.

Participants reported that inquiry-based learning in school offered them the skills of seeking information, asking questions, and active engagement in the knowledge construct of democratic education. According to Banks (2008), critical multicultural citizenship education provides students the need to examine their identifications and find ways in which they are interrelated and constructed. For example, Sally, a participant from Haiti, shared how inquiry-based learning helped her to gain knowledge in democratic education: "There was a project in American government class, that was the first time I heard of the word 'Cosmopolitanism' to mean citizens of the world who make decisions and take actions in the global interests to benefit humankind. It helped me to know benefits of global education." Most participants (15 out of 18) explained that they gained knowledge about democratic citizenship awareness through class discussions. Inquiry-based learning in social studies classroom helped them to understand the need and cause for social change. Limann, a G.E.D. student, reiterated her experience acquiring multicultural citizenship education, saying:

I like the fact we do research and project work in school on how critical issues that affects people in this world. Teachers ask us questions about social justice, equality, universal freedom in our cultural communities or countries of origin, what causes society to practice freedom, and democracy. Finding solutions to problems via research project in class helped me to understand how these facts relate to me more by playing a major role in the learning process. I have learned how to ask question and calls for social change in society. (Limann, Interview, 12/2/2013)

Limann's experience is an example of how inquiry-based learning helps participants to understand the essence of critical multicultural citizenship 
education. It fosters critical thinking skills and is inclusive of what DeJaeghere (2007) calls critical citizenship education.

Class discussions and inquiry-based learning provided these participants the opportunity to acquire knowledge of diversity, social justice, and an understanding of how the promotion of equality benefits the global society. For instance, Danny, a 15- year-old student from Haiti, described her experience in an inquiry-based classroom saying, "Inquiry-based learning approach encouraged me to be part of the learning process of what I did not know to what we learn at the end of the day." Again, Danny's comments reflect the views of many participants that inquiry-based learning provided participants with a sense of the sources of knowledge in civics with which to examine multiple perspectives on social and economic events that affect people in society at large. Participants' responses confirmed the notion that teachers should teach skills for social change so that students can make informed decisions through the evaluation of multiple perspectives (Banks, 2008; Ochoa-Becker, 2007). In the end, most of the participants acknowledged acquiring knowledge in civics, awareness of the need for social change, critical thinking, self-reflection, and democratic education via participating in inquiry-based and class discussions. The process of constructing knowledge in the classroom with the teacher serving as a guide helped Black immigrant youth acquire knowledge in critical citizenship education.

\section{The Influence of Social Media and Technology}

Social media and the use of technology played a significant role in the teaching-learning process for these Black immigrant students in American schools. Students often applied technology as a support system to aid them in learning. Most of the participants (12 out of 18) revealed learning information about civic engagement on popular social media sites such as Facebook, Instagram, Pinterest, Twitter, Tumblr, and LinkedIn. Participants indicated that they learned much information from social media by communicating and sharing stories of social events with friends via social media. Social media use increased the rate of assimilation to the cultures of the United States with less difficulty. Asif, a participant from Ethiopia, stated:

Well, I am learning more and more stuff through social media reading sharing information with friends, for example, I watch the last Presidential debate online, read comments on Facebook about what people say on the debate ... It's like I'm beginning to learn to understand what the culture is and practice it with friends here ...I guess understand what it takes to be tolerant, and work with others, the good side of keeping your identity and be good citizen as well. (Asif, Interview, 12/12/2013)

Another student, Josephine from Kenya, also emphasized that the use of technology helped her to learn and understand democratic education and pursue the quest for social action in her new school. She stated: 
Access to technology has helped me a lot to learn American government and history. I learn so much using Internet you know about elections, diversity, and equality in America. I watch TV a lot and that is where you see the Governor, and state people telling us about what is going on in Georgia State. You know, I still follow news and stories in my home country. I'm both U.S citizen and Kenyan. Just like to know what is going on there. Using social media helps me to communicate with friends and other family members concerning news in my home country [Kenya]. We share information and I have learnt a lot about democracy and various government works, trying to be international and it's helping me to know more about this world. (Josephine, Interview, 12/14/2013)

Most of the participants (13 out of 18) agreed that they maintained formal contacts and communications with friends and family as a way to keep their cultures via websites, films, music, and social media. For example, eight of the participants revealed that they watched African movies and listened to African and Caribbean music. A participant from Jamaica reiterated, "I watch both movies from Jamaica and U.S, but only listen to music from the Islands and chat with friends." Another participant from Cuba added, "I think I'm one with two things because I live in the United States but people call me by my Cuban culture, I do practice my Cuban culture, speak Spanish language at home, follow what is going on in Cuba in the news and Internet ... doing two things as one, you know." As indicated by Maira (2004) and El-Haj (2007), immigrant students believe they belong to national communities beyond the boundaries of the United States. Most of the participants (13 out of 18) agreed that social media allowed them to gain a wealth of knowledge in civics by watching television and other Internet sites. They explained that social media and access to technology helped them to embrace the concept of diversity and unity in America. Baba, a participant noted:

My geography, history, and reading teachers allow us to watch short clips of videos or documentaries in class about current events issues such as elections in the U.S., the essence of democracy, civic responsibilities of youth in American society, diversity and tolerance and help us to our opinions in class. I think it helps me to ask questions and builds my understanding of democracy and what I may need to know about social change. (Baba, Interview, 1/12/2014)

Baba's experience is a manifestation of how participants' use of social media and technology helped immigrant youth learn many concepts in citizenship education. Sarepa, a $10^{\text {th }}$ grade student from Nigeria, noted: "My teacher allowed us to play iCivics game on the Internet in social studies class. I learned much from that game about civics and governance." Participants declared that access to technology in school allowed them to acquire information about the importance of cultural pluralism in American society. Fourteen participants in this study acknowledged that access to technology offered them opportunities to listen to podcasts, chat with friends, and watch videos about civics education, democracy, 
and current events, which helped to acquire knowledge required for critical multicultural citizenship education.

\section{The Impact of Non-Educational Practices}

The majority of the participants (16 out of 18) indicated that they learned about critical multicultural citizenship education from their parents at home. Participants agreed that their horizon of critical multicultural citizenship education has been enhanced as a result of what their parents discuss with them at home. Aaron, a participant in high school, shared his experiences about how his knowledge of critical multicultural citizenship education was enhanced via discussion with parents, stating:

My parents talk politics at home, especially when watching TV program, they will then talk to me about the good things to know about your right. Sometimes I ask them questions too, that is when I feel I was discriminated at school or work place. I have learned from them the value of critical multicultural citizenship education and how it calls for the awareness of social injustices in society and ways to reduce it. (Aaron, Interview, 1/18/2014)

Another participant noted that her parents engage her in discussions about current events and political issues and that has enhanced her political engagement. She stated:

My Dad is a lawyer and he talks to me more on politics, what goes on in this country, especially during election year, I guess I have learned so much from my Dad. I don't mean we argue, just learning simple stuff like who is standing for Governor or state senator and like that. (Interview, $1 / 23 / 2014$ )

Several researchers (McIntosh, Hart, \& Youniss, 2007; Warren \& Wicks, 2011) have noted that parents can have direct influence on their children via orientation towards public participation by engaging them in discussion about current events and political issues. However, a third of the participants (6 out of 18) noted that their parents do not help them or engage them in any critical citizenship education for reasons such as the inability to speak English, job duties, and lack of political or current events. According to Callahan and Muller (2013), the socio-economic status of parents has a weaker influence on the political participation of 1.5 - and second-generation youth than on those from non-immigrant families. Participants with parents of high socio-economic status indicated higher enhancement of multicultural citizenship education than those with lower socio-economic status. This suggests that immigrant youth from higher socio-economic status have advanced political and civic engagement as compared to those with parents who lack an advanced education.

Seventeen participants in this study declared that extra curricular activities in their school such as social events, debating club, and sports offered them a 
chance to learn and understand the universalities of democracy. Extra-curricular activities allowed them to discuss the nuances of social injustices and skills for social change. Destinaa noted: "I have learned the skills of how to make informed decisions using democratic means after becoming a member of the debating club." Marri (2005) stated that the use of critical pedagogy promotes skills for democratic living through disciplinary content, and encourages traditional knowledge, building of community to facilitate positive peer relationships, and understanding of critical multicultural citizenship education.

\section{The Effect of Cultural, Social, and Language Differences}

Black immigrant youth admittedly are not used to the culture and school curriculum upon their entry to schools in the United States. They are coming from cultures that dwell much on the communal and collectivistic nature as compared to the individualized dependence in the United States (Hofstede, 2000). The majority of the participants (15 out of 18) indicated that cultural and language differences affected their ability to adjust and learn citizenship education in school. Although most participants had previous knowledge and awareness of citizenship education, it was specifically based on family relations, local or community, and global education and less dependent on what they learned in school.

They had less information on critical multicultural citizenship education. This was particularly true for students from Egypt, Liberia, and Somalia. Muhammed, a high student from Somalia, expressed his struggles in learning citizenship education, saying:

I would say it is difficult for me because sometimes I find it hard to understand what they mean by citizenship education because of my cultural and religious beliefs, it's so different they way I was taught in Somalia... less attention to it anyway - religiously, I disagree with lots of stuff they teach ... very challenging for me but getting used to it. Sometimes, I feel like I'm been discriminated in class because of my religion and culture and that is not fair. Why is it they cannot tolerate my views and practices? (Muhammed, Interview, 2/12/2014)

Statements such as these confirm findings from Nguyen's (2008) study that immigrant students view themselves as living in the U.S and not as Americans because of the issues of racism, discrimination, and exclusion they experience in their schools and communities. When asked to reiterate the cultural, social, and language challenges they face in school regarding to the understanding of citizenship education, five of the18 participants stated that the main problem concerned teacher perception. Participants indicated that teachers want them to "give away their cultural values, be ashamed of their cultural heritage, and adapt U.S. identity." Jabril, a high school student, shared her experiences: 
Some teachers make comments to me as if I don't understand citizenship education. They make you feel ashamed most of the times in class because of the example my American government teachers provides in class ... it's like there is nothing good about learning about my cultures and values. A teacher told me to just accept the cultures here and move on ... but it's just different that's all, why can't I learn both but have to forego what I know already and learn only U.S one ... very frustrating. My teachers here are teaching me to just accept the cultures and leave what I have, it's like your cultures you have is not good, leave it behind and learn new one for hope and good ... I feel sad and inferior at school because everything I have is no better. (Jabril, Interview, 2/20/2014)

Greenbaum (1974) acknowledged that U.S. schools taught immigrant students hope and shame; that is, immigrant students were made to feel ashamed of their home cultures and given the chance to start to learn the cultures again in function in the mainstream cultures. Participants who migrated from non-English speaking countries also expressed that the use of English language (grammar) by teachers and students was a major challenge to them. The majority of the participants (9 out of 18) in the study expressed disbelief about the way they were led to feel ashamed in the quest to learn multicultural citizenship education at school. Participants noted that while teachers strive to present diverse curriculums to promote understanding of multicultural citizenship education and cultural awareness, for several reasons they rarely achieve these goals because some of their teachers lack relevant knowledge and experience about participants' cultural backgrounds, their cultural perspectives, and the voices of their educational and social experiences in American society. They contended that school authorities, including teachers, marginalized them based on their cultures.

\section{Discussions and Implications}

This article has examined the factors that promote the enhancement and awareness of critical multicultural citizenship education among Black immigrant youth as well as identified challenges for Black immigrant youth in the acquisition of critical multicultural citizenship education. In doing so, it aims to identify educational implications of critical multicultural citizenship education for immigrant youth and teachers in U.S. schools. The story developing from the findings indicates that Black immigrant youth navigate their understanding and awareness of critical multicultural citizenship education via four major factors: class discussion and inquiry-based learning; social media and technology; noneducational practices; and cultural, social, and language differences. Based largely on student interviews and supplemented by several reflections and observations, we have demonstrated the various educational and noneducational patterns through which Black immigrant youth learn and transition to 
be on the path of what is termed "effective citizen" or to assimilate into the U.S. cultural, social, and traditional values, and/or demonstrate active citizenship.

Findings show that the infusion of inquiry-based learning helped to promote civic awareness and to understand students' multiple and complex identities as immigrant youth who come to the school system with different cultural, social, and language backgrounds. This learning provided students with the opportunity to discuss the intricacies of global affairs or government policies and held potential for influencing their lives as citizens (Dilworth, 2004; McLaren, 1997). Findings in this study are consistent with Freire's (1999) assertion that critical multicultural citizenship education opens dialogue that results from the emergence of reflection and leads citizens to take social action as a means for improving the society in which they live.

Moreover, our findings demonstrate that the use of technology and social media helped to advance the awareness and knowledge of multicultural citizenship education for participants. Participants had the chance to communicate with friends and families and to maintain contacts with their homeland cultures via social media and use of the Internet. Their participation in extra-curricular activities helped the efforts of these Black immigrant youth to gain awareness and knowledge of citizenship education. Study findings also agree with Marri's (2005) assertion that students understand critical multicultural citizenship education through stages of critical pedagogy, building of knowledge and thorough disciplinary content. Notwithstanding, the majority of participants seemed to advance their knowledge of citizenship education through civic engagement and political education using an avenue not often acknowledged: their parents. Further, our findings agree with McIntosh, Hart and Younnis (2007) that parents help to educate their children about civic responsibilities, current events, understanding of equality, voting, and cultural citizenship so that they can assimilate with less difficulty. For example, most participants (16 out of 18) indicated that their parents helped them to gain knowledge about critical multicultural citizenship education via discussion of current events issues at home.

Notably, the study showed that a lack of knowledge on the part of teachers and students about participants' cultural backgrounds led these participants to be marginalized and discriminated against in ways that derailed their understanding of critical multicultural citizenship education. These findings support the research which states that students in U.S. schools teach immigrant youth hope and shame, as they are made to feel ashamed of the cultures and traditions of their country of origin and assured of hope and prosperity as they culturally learn to assimilate to join U.S. mainstream (Greenbaum, 1974). Despite the challenges faced in their quest to acquire citizenship education because of their cultural, social, and language differences and in spite of cultural and language factors that derailed the enhancement of participants' efforts to gain awareness and knowledge of citizenship education, participants' narratives ultimately reflected the constructs of participatory citizenship education and social justice education. These findings extend prior research that shows that 
critical citizenship education offers students the ability to make informed decisions to achieve democratic aims (Banks, 2008; Ochoa-Becker, 2007; Robertson, 2008).

This study is not without its limitations. First, this study has a small sample size of 18 Black immigrant youth. Study findings cannot be used to generalize the factors and challenges of promoting critical multicultural citizenship education in U.S. schools that were faced by the 18 youth in this study to all Black immigrant youth. The educational implications of this research are considerably more complex, specifically as they relate to the multiple socio-cultural backgrounds of Black immigrants. Researchers must continue to disentangle the roles of ethnicity, class, cultural, language differences, and immigration in the citizenship educational outcomes of the different groups to identify the factors that contribute to multicultural citizenship for certain immigrant populations as opposed to others.

Given the heterogeneity in the African and Caribbean population, unraveling these factors is significant if the field is to account for specific factors that influence the advancement and success of multicultural citizenship education among Black immigrant youth. Another implication of the findings is the need for teachers to infuse into their instructional process the use of classroom discussions, inquiry-based learning, and social media, so that learning is made more meaningful and relevant to students' lives (Banks, 2004a, 2008; Slavin, 2006). The use of these methods can help students better understand and appreciate the concept of citizenship education so they can improve the new worlds in which they function (Banks \& Banks, 1999; El-Haj, 2007; Maira, 2004). Doing so will facilitate students' development of human connections to people around the world, as well as help them forge a commitment to internalize democratic beliefs and values and acquire critical thinking skills (Appiah, 2006; Banks, 2008; Nussbaum, 2002) in the destination country of the United States.

\section{Notes}

1. We use pseudonyms throughout the study to represent student participants and maintain participant confidentiality.

2. We define Black immigrant youth as immigrant youth who were originally born in Africa and or Caribbean Islands to one or both African and or Caribbean parents and who had migrated to the United States to live with their parent or parents/guardian and attending school.

\section{References}

Alba, R., \& Nee, V. (2003). Remaking the American mainstream: Assimilation and contemporary immigration. Cambridge, MA: Harvard University Press. 
American Community Survey (2014). Selected characteristics of the native and foreign-born populations. U.S. Census Bureau. Retrieved from https://www.census.gov/programs-surveys/acs/

American Community Survey (2012). Selected characteristics of the native and foreign-born populations. U.S. Census Bureau. Retrieved from https://www.census.gov/programs-surveys/acs/

Apple, M. W., \& Beane, J. A. (2007). Democratic schools: Lessons in powerful education (2nd ed.). Portsmouth, $\mathrm{NH}$ : Heinemann.

Appiah, K. A. (2006). Cosmopolitanism: Ethnics in a world of strangers. New York, NY: Norton.

Au, W. (2007). High-stakes testing and curricular control: A qualitative metasynthesis. Educational Researcher, 36(5), 258-267.

$\mathrm{Au}, \mathrm{K}$. (2006). Multicultural issues and literacy achievement. Mahwah, NJ: Lawrence Erlbaum.

Banks, J. A. (2008). Diversity, group identity, and citizenship education in a global age. Educational Researcher, 37(3), 129-139.

Banks, J. A. (2007). Educating citizens in a multicultural society (2nd ed.). New York, NY: Teachers College Press.

Banks, J. A. (2004a). Diversity and citizenship education: Global perspectives. San Francisco, CA: Jossey-Bass.

Banks, J. A. (2004b). Introduction: Democratic citizenship education in multicultural societies. In J. A. Banks (Ed.), Diversity and citizenship education: Global perspectives (pp. 3-15). San Francisco, CA: JosseyBass.

Banks, J. A., \& Banks, C. A. M. (1999). Teaching strategies for the social studies: Decision-making and citizen action. New York, NY: Longman.

Browning, L., Davies, B., \& Resta, V. (2000). What do you mean "think before I act"? Conflict resolution with choices. Journal of Research in Childhood Education, 14(2), 232-238.

Callahan, R. M., \& Muller, C. (2013). Coming of political age: American schools and the civic development of immigrant youth. New York, NY: Russell Sage Foundation.

Castro, A. (2010). Challenges in teaching for critical multicultural citizenship: Student teaching in an accountability-driven context. Action in Teacher Education, 32(2), 97-109.

Charmaz, K. (2006). Constructing grounded theory: A practical guide through qualitative analysis. London, UK: Sage.

Creswell, J. W. (2009). Research design: Qualitative, quantitative, and mixed methods approaches (2nd ed.). Thousand Oaks, CA: Sage. 
Creswell, J. W., \& Miller, D. (2000). Determining validity in qualitative inquiry. Theory Into Practice, 39(3), 124-130.

DeJaeghere, J. G. (2007). Intercultural and global meanings of citizenship education in the Australian secondary curriculum: Between critical contestations and minimal construction. In E. D. Stevick \& B. A. Levinson (Eds.), Reimagining civic education: How diverse societies form democratic citizens (pp. 293-316). Lanham, MD: Rowman \& Littlefield.

Dei, G. (2002). Learning culture, spirituality and local knowledge: Implications for African schooling. International Review of Education, 48, 355-360.

Dilworth, P. P. (2004). Multicultural citizenship education: Case studies from social studies classrooms. Theory and Research in Social Education, 32(2), 153-186.

El-Haj, T. R. A. (2007). "I was born here, but my home, it's not here": Educating for democratic citizenship in an era of transnational migration and global conflict. Harvard Educational Review, 77(3), 285-316.

Freire, P. (1999). Pedagogy of the oppressed. New York, NY: Continuum.

Gall, M. D., Borg, W. R., \& Gall, J. P. (2007). Educational research: An introduction $\left(8^{\text {th }}\right.$ ed.). White Plains, NY: Longman.

Gay, G. (2000). Culturally responsive teaching: Theory, research, and practice. New York, NY: Teachers College Press.

Gee, J. P. (2013). The anti-education era: Creating smarter students through digital learning. New York, NY: Palgrave Macmillan.

Gibson, M. A. (1989). Accommodation without assimilation: Sikh immigrants in an American high school. Ithaca, NY: Cornell University Press.

Giroux, H. A. (2005). Schooling and the struggle for public life: Democracy's promise and education's challenge. Boulder, CO: Paradigm.

González, N., Moll, L. C., \& Amanti, C. (2005). Funds of knowledge: Theorizing practices in households, communities, and classrooms. Mahwah, NJ: Lawrence Erlbaum.

Graham, P. A. (2005). Schooling in America: How the public schools meet the nation's changing needs. New York, NY: Oxford University Press.

Greenbaum, W. (1974). America in search of a new ideal: An essay on the rise of pluralism. Harvard Educational Review, 44(3), 411-440.

Haste, H., \& Hogan, A. (2006). Beyond conventional civic participation, beyond the moral-political divide: Young people and contemporary debates about citizenship. Journal of Moral Education, 35, 473-493.

Hoechsmann, M., \& Poyntz, S. (2012). Media literacies: A critical introduction. London, U.K.: Wiley-Blackwell.

Hofstede, G. (2000). Culture's consequences: comparing values, behaviors, 
institutions, and organizations across nations (2nd ed.). Thousand Oaks, CA: Sage Publications.

Jensen, L. (2008). Immigrants' cultural identities as sources of civic engagement. Applied Developmental Science, 12(2), 74-83.

Jensen, L. A., \& Flanagan, C. A. (2008). Immigrant civic engagement: New translations. Applied Developmental Science, 12, 55-65.

Knight, M., \& Watson, V. W. M. (2014). Toward participatory communal citizenship: Rendering visible the civic teaching, learning, and actions of African immigrant youth and young adults. American Educational Research Journal, 51(3), 539-566.

Knight, M. (2011). "It's already happening": Learning from civically engaged transnational immigrant youth. Teachers College Record, 1113, 12751292.

Koopmans, R., Statham, P., Giugni, M., \& Passy, F. (2005). Contested citizenship: Immigration and cultural diversity in Europe. Minneapolis, MN: University of Minnesota Press.

Konczal, L. (2001). The academic orientation of first and second-generation Nicaraguan immigrant adolescents. Unpublished doctoral dissertation, Florida International University, Miami, FL.

Ladson-Billings, G. (2004). Culture versus citizenship: The challenge of racialized citizenship in the United States. In J. A. Banks (Ed.), Diversity and citizenship education: Global perspectives (pp. 99-126). San Francisco, CA: Jossey-Bass.

Levinson, M. (2012). No citizen left behind. Cambridge, MA: Harvard University Press.

Lincoln, Y. S., \& Guba, E. G. (2000). Naturalistic inquiry. Beverly Hills, CA: Sage.

Marri, A. R. (2005). Building a framework for classroom-based multicultural democratic education: Learning from three skilled teachers. Teachers College Record, 107(5), 1036-1059.

Maira, S. (2004). Imperial feelings: Youth culture, citizenship, and globalization. In M. Suárez-Orozco \& D. B. Qin-Hilliard (Eds.), Globalization, culture, and education in the new millennium (pp. 203-234). Berkeley, CA: University of California Press.

Marshall, T. H. (1964). Class, citizenship, and social development: Essays of T.H. Marshall. Westport, CT: Greenwood.

McCabe, K. (2011). African immigrants in the United States. Migration Information Source. Retrieved from http://www. migrationinformation.org/

McIntosh, H., Hart, D., \& Youniss, J. (2007). The influence of family political discussion on youth civic development: Which parent qualities matter? Political Science and Politics, 40(3), 495-499. 
McLaren, P. (1997). Revolutionary multiculturalism: Pedagogies of dissent for the new millennium. Boulder, CO: Westview Press.

Merriam, S. B. (2009). Qualitative research: A guide to design and implementation. San Francisco, CA: Jossey-Bass.

Moon, S., \& Park, C. Y. (2007). Media effects on acculturation and biculturalism: A case study of Korean immigrants in Los Angeles' Korea town. Mass Communication and Society, 10(3), 319-343.

Nguyen, D. (2008). In between worlds: How Vietnamese immigrant youth construct social, cultural, and national identifications. Unpublished doctoral dissertation, University of Washington, Seattle.

Nieto, S. (1999). The light in their eyes: Creating multicultural learning communities. New York, NY: Teachers College Press.

Nussbaum, M. (2002). Patriotism and cosmopolitanism. In J. Cohen (Ed.), For love of country (pp. 2-17). Boston, MA: Beacon.

Ochoa-Becker, A. S. (2007). Democratic education for social studies: An issuescentered decision making curriculum. Greenwich, CT: Information Age.

Ogbu, J. (1991). Immigrant and involuntary minorities in comparative perspective. In J. Ogbu \& M. Gibson (Eds.), A comparative study of immigrant and involuntary minorities (pp. 3-33). New York, NY: Garland.

Olsen, L. (2001). Public education, immigrants, and racialization-the contemporary Americanization project. In G. Gerstle \& J. Mollenkopf (Eds.), E Pluribus Unum? Immigrants, civic life, and political incorporation (pp. 371-411). New York, NY: Russell Sage Foundation.

Parker, W. C., \& Hess, D. (2001). Teaching with and for discussion. Teaching and Teacher Education, 17, 273-289.

Portes, A., \& Rumbaut, R. (2001). Legacies: The story of the immigrant second generation. Berkeley, CA: University of California Press and Russell Sage Foundation.

Ramakrishnan, S. K., \& Bloemraad, I. (2008). Civic hopes and political realities: Immigrants, community organizations, and political engagement. New York, NY: Russell Sage Foundation.

Robertson, E. (2008). Teacher education in a democratic society: Learning and teaching the practices of democratic participation. In M. McIntyre (Eds.), Handbook of research on teacher education: Enduring questions in changing contexts (3rd ed., pp. 27-44). New York, NY: Routledge.

Slavin, R. E. (2006). Educational psychology: Theory and practice $\left(8^{\text {th }}\right.$ ed.). Boston, MA: Pearson Education, Inc.

Suárez-Orozco, C., \& Suárez-Orozco, M. M. (1995). Transformations: Migration, family life, and achievement motivation among Latino and White adolescents. Stanford, CA: Stanford University Press. 
Suárez-Orozco, C., \& Suárez-Orozco, M. M. (Eds.). (2001). Children of immigration. Cambridge, MA: Harvard University Press.

Stepick, A., \& Stepick, C. D. (2000). Peer groups, identity, and academic engagement in multi-ethnic US high schools. Paper presented at American Anthropological Association Annual Conference, San Francisco, CA.

U.S. Bureau of the Census. (2014). Profile of the foreign-born population in the United States. Washington, DC: U.S. Government Printing Office.

U.S. Census Bureau. (2010). Selected population profile in the United States (Report No. S0201). Retrieved from http://www2.census.gov/ acs2014_1yrsummaryfile

Warren, R., \& Wicks, R. H. (2011). Political socialization: Modeling teen political and civic engagement. Journalism \& Mass Communication Quarterly, 88(1), 156-175.

Waters, M. (1999). West Indian immigrant dreams and American realities. Cambridge, MA: Harvard University Press.

Young, I. M. (2000). Inclusion and democracy. New York, NY: Oxford University Press.

\section{Appendix A}

Factors and Challenges of Black Immigrant Youth in Promoting Critical Multicultural Citizenship Education

\section{Interview Protocol}

\section{Black Immigrant Youth}

1. What is your name?

2. Where are you from originally?

3. What language are spoken in your home?

4. How many people live in your household, including yourself?

5. What is the hardest thing about immigrating to the United States?

6. What is your relationship to the people that live in your household?

7. Are any of them U.S. citizen or citizens?

8. When did your parents move to the U.S? 
9. What is the educational level of your parents and/or guardian?

10. What has been your experience growing up or living in the cities in the U.S?

11. Have you been involved in any activities since moving to the U.S?

12. Did you participate in any activity before moving to the U.S?

13. What school and home activities do you participate in your country before moving to the U.S.

14. Do you have any experience of civic engagement in school before moving to the U.S?

15. Do you discuss any civic or political issues with your parents at home?

16. How often do you discuss civic or political issues with your parent or friends or families?

17. What was the purpose of these activities in school?

18. How do you keep in contact with your friends and families?

19. What were your educational experiences at school before moving to the U.S?

20. How was school like back home?

21. What do you like most about school back home?

22. What do you like least about school in the U.S?

23. Did you participate in any civic education activities in school in your country before moving to the U.S?

24. What were the classes or courses in your previous school like?

25. Did you have the chance to discuss or participate in critical citizenship education?

26. If so, please provide more examples.

27. If not why?

28. What was your experience in extra-curricular activities in your previous school?

- Why did you choose to participate in extra-curricular activities?

- Were they local, regional, national or international?

\section{Education in the United States}

29. Tell me about what was challenging for you after arriving in the U.S. and how you dealt with these challenges.

30. What do you think helped you to adapt new school and achieve success in school? 
31. What is the most difficult thing or experience about school in the U.S.?

32. Do you have any academic challenges in school?

33. What are some of the academic and non-academic challenges you are facing in school?

34. How would you describe the racial/ethnic/gender make up of your school in the U.S?

\section{Technology}

35. Do you have access to computer and Internet at home and school?

36. Describe how Internet and computer help you to be become aware of the information in the U.S?

37. What knowledge did you gain from using Internet at both school and home?

38. How often do you use Internet and or technology to learn citizenship education at school and home?

39. What activities in technology (Internet) offered you opportunity to learn citizenship education in the U.S?

40. In what ways do you use technology (Internet, chat, social media) to get and share information about citizenship education and/or civic education (activities, events, follow current events)?

41. Do you watch television at home?

42. How many hours of television do you watch?

43. What information did you gain from watching television?

\section{Citizenship Education/Civic Participation}

44. What is your understanding of citizenship education?

45. Could you describe what helps you to gather information about your right as citizen?

46. In which class or course do you discuss civic events or political, historical, or environmental issues such as (environmental protection, global education, global warming, and social activism)?

47. How are you influenced by civic and citizenship education at school?

48. What are some of the challenges you face at school regarding multicultural citizenship education?

49. How often do you participate in civic discussions in class? 
50. In what ways did your teachers' method of teaching influence you thinking of what it means to be a good citizen?

51. In what class do you discuss social issues (voting, social change, and democracy)?

52. Describe the best ways a particular activity or project in class allowed you to gain more knowledge in critical multicultural citizenship education in school?

53. What classroom activity allows you to express your opinion in citizenship education?

54. Has anyone treated you differently because of your cultural or ethnic background [Africa or the Caribbean]?

55. Are there times when felt you were mistreated in the U.S? Can you explain and provide one example of when it happened? (Probes: what happened? Why do you think it happened? Have you had other similar experiences? By which group? Why?)

56 . What are your plans for the future?

57. Is there any additional information you want to share or add about what factors promote and/ or challenge critical multicultural citizenship education knowledge in both school and home?

\section{Author Contact}

Alex Kumi-Yeboah: akumi-yeboah@albany.edu

State University of New York-Albany, 1400 Washington Avenue

Albany, NY 12222

U.S. A.

Patriann Smith: patriann.smith@ttu.edu

Texas Tech University

2500 Broadway

Lubbock, TX 79409-10

U. S. A. 